\title{
Industrial Property in pandemic times: the Brazilian panorama of requests for protection of pandemic- related products projects at National Institute of Industrial Property
}

\author{
Diogo Pontes Costa ${ }^{*}$ (D), Ruan Eduardo Carneiro Lucas ${ }^{2}$ (D), Diego de Castro Fettermann² (D), Carmen Elena Martinez Riascos ${ }^{2}$ (D), \\ Eugenio Andrés Díaz Merino ${ }^{2}$ (1) \\ ${ }^{1}$ Programa de Pós-graduação em Design, Universidade Federal de Santa Catarina - UFSC, Florianópolis, SC, Brasil \\ 2Programa de Pós-graduação em Engenharia de Produção, Universidade Federal de Santa Catarina - UFSC, Florianópolis, SC, Brasil
}

\begin{abstract}
The Coronavirus Pandemic (COVID-19) imposed unexpected demands on society, intensifying the development of new products projects that sought to mitigate the contamination risks. It was possible to identify a series of projects aiming for the protection of the people, especially for those inserted in hospital environments to fight COVID-19. Therefore, the present article aims to identify the Brazilian overview of applications for Patents and Industrial Designs related to aid and protect the people, during the year of 2020, registered with the National Institute of Industrial Property, limited to protective equipment, medical equipment and furniture. To meet the proposed objectives, a bibliographic research was carried out, with a quantitative and theoretical approach, along with an exploratory and descriptive objective; regarding the methodological procedures, the model of Systematic Review was used 20 patent registrations and 22 industrial design registrations were identified. It was possible to observe that there is a diversity of classes of products and that the largest number of projects is related to facial protection, providing greater technical knowledge for the creation and development of similar projects. It was also found a predominance of projects from individuals and from private institutions, that the South and Southeast regions registered more protection requests, and that the inventors were mostly from the areas of Engineering, Medicine, and Design.
\end{abstract}

Keywords: COVID-19, industrial property, patent, industrial design.

\section{Introduction}

The year of 2020 was marked by the new coronavirus pandemic, SARS-CoV-2, which produces the COVID19 disease. This virus is the third mutation of the coronavirus (CoVs) that has emerged in the last twenty years and the first to cause a pandemic. The first mutation occurred in 2002 and the second in 2012, causing the severe acute respiratory syndrome (SARS) and the middle east respiratory syndrome (MERS), respectively (Casas et al., 2020; Wu et al., 2020).

The COVID-19 was firstly identified in the city of Wuhan, China, in December 2019. Since then, there has been a rapid spread of the disease around the world, the first case in Brazil being confirmed in February 2020 (Croda et al., 2020). In this country, the great propagation capacity meant that, until 22 December 2020, about 7,263,619 cases and 187,921 deaths were confirmed (Brasil, 2020). The lethality rate of this disease is around $2.5 \%$, however, about $20 \%$ of patients require hospital medical assistance, and $15 \%$ require care in Intensive Care Units (ICU) due to breathing problems (Brasil, 2020; Suzumura et al., 2020).

These numbers reflected in the high utilization of ICU beds and, in view of the possibility of a collapse of the health system, they also demanded the creation of field hospitals (Aires, 2020; Rache et al., 2020; Noronha et al., 2020). This scenario generated a worldwide effort to develop new solutions and products that would help in the treatment of infected people or minimize the possibility of contamination.

One of the products developed to aid in the treatment of COVID-19 was the pulmonary ventilator, as the combination of high demand, limited industry capacity, and high manufacturing complexity meant that already active companies did not absorb all market demand in such a short time. Thus, to avoid deaths due to the scarcity of this equipment, specialists, researchers, entrepreneurs, and volunteers concentrated their efforts on the creation

Received: May 3, 2021. Accepted: June 29, 2021.

*Corresponding author: Diogo Pontes Costa. E-mail: diogopontes102@gmail.com 
of alternative ventilators (Suzumura et al., 2020). Other products, aimed to personal hygiene, for instance (alcohol gel sanitizer, alcohol 70\% solution, disposable apron, procedure gloves, goggles), were also developed, as the containment measures for this disease are taken, mainly, through hygiene care (Jefferson et al., 2011; Saraiva et al., 2020).

Facial masks are also important in containing the spread of the virus, when used correctly, they interrupt the dispersion of the expelled particles through coughing or sneezing (van der Sande et al., 2008; Garcia, 2020). Thus, it was observed a propulsion of these products in the market, such as home masks, surgical masks, N95 masks, among others (Girardi et al., 2020; Saraiva et al., 2020; Souza \& Farias, 2020).

These products show that, despite the crisis period, there were opportunities to develop new solutions and products. To protect these inventors, there is the registration of Industrial Property (IP), which is governed by current Brazilian legislation by the Industrial Property Law no. 9,279/96 (Ferreira et al., 2009). This law governs the Letter Patent and the registration of industrial design. The Letter Patent is a document that details the invention and allows, from legal protection, the exercise of legal rights of use by the inventor and prevents third parties from exploiting it improperly (Instituto Nacional da Propriedade Industrial, 2020b; World Intellectual Property Organization, 2009).

The registration of industrial design, in turn, is a temporary property title granted to individuals who have developed a structure that has "an ornamental plastic shape of an ornamental object or set of lines and colors that can be applied to a product, providing a new and original look in its external configuration that can serve as an industrial manufacturing type" (Instituto Nacional da Propriedade Industrial, 2020a; World Organization of Intellectual Organization, 2009).

In Brazil, Industrial Property and, consequently, the Letter Patent and the registration of industrial design are managed by the National Institute of Industrial Property (INPI), which is a federal agency linked to the Ministry of Economy, and its mission is to stimulate innovation and competitiveness at the service of technological and economic development in Brazil (Instituto Nacional da Propriedade Industrial, 2016).

When these projects are not registered, good ideas can be wrong used by third parties, and the economic impact of industrial patents and registrations is minimizing. For this, the focus of this article is the identification and analysis of projects related to COVID-19 officially registered in Brazil. Given this context, the research question was: which patents and industrial designs developed to assist and protect people from the new coronavirus were register with the INPI?

Thus, the paper aims to identify the Brazilian overview of applications for Utility Model Patents and Industrial Designs, registered with the INPI, related to the assistance and protection of people from the new coronavirus of Severe Acute Respiratory Syndrome-2 (SARS-CoV-2).

This work is justified on the following aspects: (i) it provides a Brazilian overview of the status of patents and industrial designs related to the new coronavirus, limited to protective equipment, medical equipment and furniture; and (ii) makes it possible to map the profile of these inventors.

This work is limited to products that were registered in the INPI, therefore, those that were presented in other formats (for example, article and technical note) were not analyzed. As the INPI is a member of the World Intellectual Property Organization (WIPO), the scope used in this study can be replicated and compared with the information provided by other members.

This text has five additional sections. The second is presents the intellectual property theory. The third is presents the methodological aspects to the development of the study. The fourth shows the results obtained. The fifth discusses the results, and the sixth the conclusions.

\section{The intellectual property}

The cognitive and intellectual capacity of the human being allows the emergence of ideas, inventions, and innovations. To protect them, Intellectual Property (PePI) appears as a branch of law that takes care and guarantees to inventors the legal possibility of reward for their own creation (Klosowski et al., 2020; World Intellectual Property Organization, 2016). In other words, it can be understood as the set of immaterial rights that affect human productions in the industrial, scientific, literary, or artistic domains that have economic value (Klosowski et al., 2020; World Intellectual Property Organization, 2016).

It is divided into copyright, industrial property: trademarks, patents, geographical indication and industrial design, and sui generis rights (Silva et al., 2019; Loiola \& Mascarenhas, 2013). Figure 1 presents these categories and their respective typologies. 


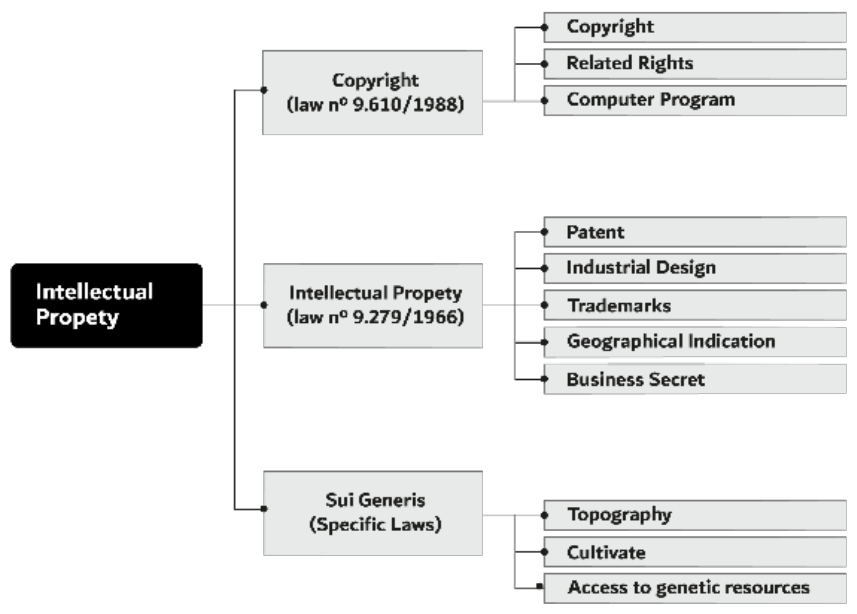

Figure 1. Overview of intellectual property in Brazil. Source: Adapted from Klosowski et al. (2020) and Confederação Nacional da Indústria (2014).

This study focuses on the Intellectual Property category, which, regulated by Law No. 9,279, covers the following types: (i) trademark; (ii) patent; (iii) industrial design; (iv) geographical indication and (v) business secrets (Confederação Nacional da Indústria, 2014; Biachini \& Russo, 2019).

In Brazil, the National Institute of Industrial Property (INPI), which is the main structure for the concession of intellectual property, is responsible for managing the Brazilian system for granting and guaranteeing industrial property rights (Confederação Nacional da Indústria, 2014). Among the typologies mentioned, which are also within the scope of the INPI, this paper is dedicated to two of them: patent and industrial design. Regarding the first, it can be understood as being:

[...] a temporary title of ownership over an invention or utility model, granted by the State to inventors or authors or other natural or legal persons with rights over creation. With this right, the inventor of the patent holder has the right to prevent third parties, without their consent, from producing, using, offering for sale, selling, or importing the product covered by their patent and/or process or product obtained directly by process patented by him. In return, the inventor undertakes to reveal in detail all the technical content of the matter protected by the patent. (Instituto Nacional da Propriedade Industrial, 2016).

Patents, according to the INPI, can be classified into three types: (i) invention patent, which is valid for 20 years from the filing date; (ii) utility model patent, which is valid for 15 years from the filing date; and (iii) invention addition certificate. The description of each of them is shown in Table 1.

Table 1. Patent types and expiration date.

\begin{tabular}{|c|c|c|}
\hline TYPE & DESCRIPTION & VALIDATE \\
\hline Invention Patent (IP) & $\begin{array}{l}\text { "Products or processes that meet the requirements of } \\
\text { inventive step, novelty and industrial application" }\end{array}$ & 20 years from the deposit date \\
\hline Utility Model Patent (MU) & $\begin{array}{l}\text { "Object of practical use, or part of it, susceptible to } \\
\text { industrial application, which presents a new form of } \\
\text { disposition, involving an inventive act, which results in a } \\
\text { functional improvement in its use or in its manufacture" }\end{array}$ & 15 years from the deposit date \\
\hline $\begin{array}{l}\text { Certificate of Addition of } \\
\text { Invention }(\mathrm{C})\end{array}$ & $\begin{array}{l}\text { "Improvement or development introduced in the } \\
\text { intervention object, even if devoid of inventive step, but } \\
\text { still within the same inventive concept" }\end{array}$ & $\begin{array}{l}\text { The certificate will be accessory to } \\
\text { the patent and with the same end date } \\
\text { as this }\end{array}$ \\
\hline
\end{tabular}

Source: Adapted from Instituto Nacional da Propriedade Industrial (2020b).

Since Law No. 9,279 came into effect, patents have not been used to protect industrial design. This protection started to be made by the registration of Industrial Design, which can be understood as a temporary title granted by the State and that during the registration term, without the proper authorization, the manufacture, commercialization, import, use, and sale is forbidden (Instituto Nacional da Propriedade Industrial, 2016). It is possible to register anything that falls under Article 95 of Law No. 9,279, which defines industrial design as 
[...] the ornamental plastic shape of an object or the ornamental set of lines and colors that can be applied to a product, providing a new and original visual result in its external configuration and that can serve as an industrial manufacturing type. (Brasil, 1996).

Patents and registrations of industrial design shield inventors and ensure their rights, as they prevent third parties from misusing them (Oliveira et al., 2018). These have become even more relevant today, as the SARSCoV2 (COVID-19) pandemic has demanded the development of products to meet the new demands of this period of crisis (Belhouideg, 2020).

\section{Methodology}

In order to meet the objective proposed in this study, theoretical research was carried out, with an exploratory purpose. Referring to technical procedures, it is classified as Bibliographic Review with a quantitative approach, as it contemplated the bibliographic analysis of the amount of registrations of intellectual property (Marconi \& Lakatos, 2011).

The methodology used was the Systematic Review, containing a reproducible and impartial process, to answer a well-defined research question, and characterized by being methodologically comprehensive, transparent, and replicable (Donato \& Donato, 2019). Systematic reviews are essential for healthcare providers, policymakers, and other decision-makers, who would otherwise be confronted by an overwhelming volume of research on which to base their decisions (Page et al., 2021).

To meet the aim of this research, the review was divided into six steps: (i) Defining research questions; (ii) Producing a protocol investigation; (iii) Defining the inclusion and exclusion criteria; (iv) Project selection; (v) Data extraction and documentation; (vi) Data synthesis and documents cataloguing (adapted from Donato \& Donato, 2019).

\subsection{Defining research questions}

To obtain the applicable conclusions and meet the review aim, research questions were elaborated. The objective is to identify and tabulate patents and industrial designs, limited to protective equipment, medical equipment, and furniture, intended to combat COVID-19, registered on the INPI platform during the year 2020. These provided the main information for each project, and they can be used as a reference in the development of new project.

Then, we intend to answer the following questions: What patents and industrial designs related to COVID-19 were registered with the INPI during the year 2020? Which patents and industrial designs related to COVID-19 have registered with the INPI during 2020? Which classes of products have registered? Who are the depositors and from which States? Who are the inventors and in what is their academic background?

The answers to these questions make it possible to identify the Brazilian scenario of patent applications and industrial registrations.

\subsection{Producing a protocol investigation}

With respect to the reliability of the research sources, the quality of the protocol and the data analyzed, searches were carried out in the database of the National Institute of Industrial Property, linked to the Ministry of Economy of the Brazilian government, as the research interest was focused on understanding the overview of registration applications in Brazil.

The searches with the INPI database were divided into two steps: the first using the PePI tool in the area for Patents, and the second using the PePI tool in the area for Industrial Designs (Instituto Nacional da Propriedade Industrial, 2020a, 2020b). As for the keywords used for the search, after previous research in scientific literature, the following were chosen: covid19; protective equipment; medical equipment; furniture and facial protector. The survey was carried out between December 2020 and January 2021, and documents registered in 2020 were selected.

The search for Patents on the Consultation page of the INPI Database permits applying filters to streamline the process; among the possible combinations, after a series of tests carried out by the researchers, 6 combinations were used for each keyword, as shown in Figure 2. The first two combinations (1a) all word - title and (1b) all the word - abstract selection the projects that have all the search keywords, but not necessarily in the order; the third and fourth (2a) exact expression - title and (2b) exact expression - abstract select projects that have keyword accuracy, in relation to gender, number, grade and order; the last two combinations (3a) any for the word - title and (3c) any for the word - abstract, selection all the projects that have at least one of the keywords. 


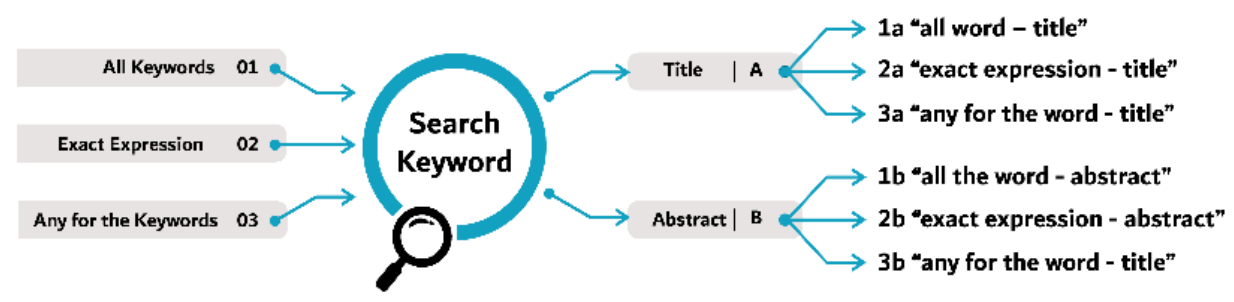

Figure 2. Combinations searched. Source: Author's elaboration (2020).

Regarding Industrial Design, three combinations were used for each keyword: (1a) all words - title; (2a) exact expression - title, and (3a) any for the words - title. The words were only combined with the "titles" filter, because the website does not provide the "abstract", as shown in Figure 3.

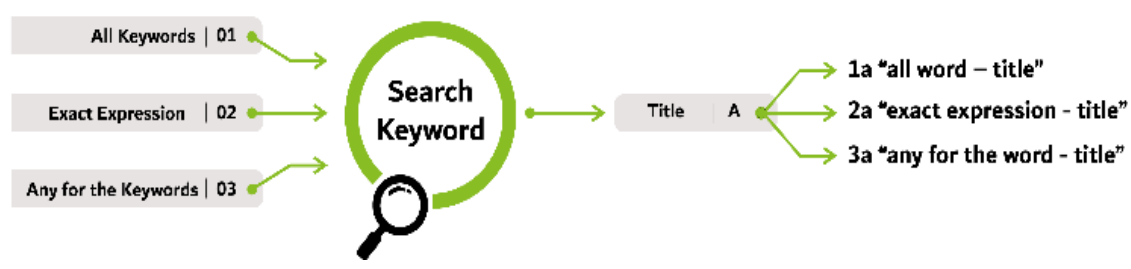

Figure 3. Industrial design combinations. Source: Author's elaboration (2020).

Each keyword went through this process, in both cases, and the searches were organized, filtered, synthesized, and tabulated in an Excel sheet.

\subsection{Inclusion and exclusion criteria}

Two filters were used with the inclusion and exclusion criteria, the first one:

- Inclusion Criteria: orders registered in 2020; be related to COVID-19;

- Exclusion Criteria: duplicated orders; projects related to medicines, vaccines, processes, systematizations, services.

In the second filter:

- Inclusion Criteria: protective equipment, medical equipment and furniture.

- Exclusion Criteria: duplicated documents and those that were still being analyzed and without a project image registration were excluded.

\subsection{Project selection}

In addition to these criteria, the documents were read in full and selected works that were consistent with the keywords and objective of this research.

\subsection{Data extraction and documentation}

To stratify the desired data in the research, two Excel sheets were organized separately to generate the graphs and tables, the first with documents related to patents and the second with industrial designs.

\subsection{Data synthesis and document cataloging}

The last step consisted of synthesizing the information that answered the research questions, and consequently the research aim. To do so, tables, graphs, and infographics were compiled, containing the amount and description of the main information, such as: process number, title, product class, depositor, name of those involved in the project, and academic background.

To identify the academic background (complete graduation in higher education), searches were carried out on two digital platforms, the first on the Lattes platform linked to CNPq (National Council for Scientific and Technological Development), which integrates the curriculum data of students and researchers in Brazil and has become a national standard, and the second on LinkedIn, known as a business social network. Both platforms allow free access to the desired information and depend on the individual's self-declaration. 


\section{Results}

According to the criteria presented in the methodological procedures and the research investigation questions, it was possible to identify a wide range of projects from different locations. The results were divided into two main topics, the first related to patents and the second to industrial design, according to the next topics.

\subsection{Patents}

The patent search in the INPI database was carried out between 18 and 19 December 2020 and returned a total of 73,658 documents. Based on the first filter criteria, 27 documents remained for the second filter, and 20 patents remained for data synthesis and documents cataloging, through a visual panel. This filtering process is presented in Figure 4.

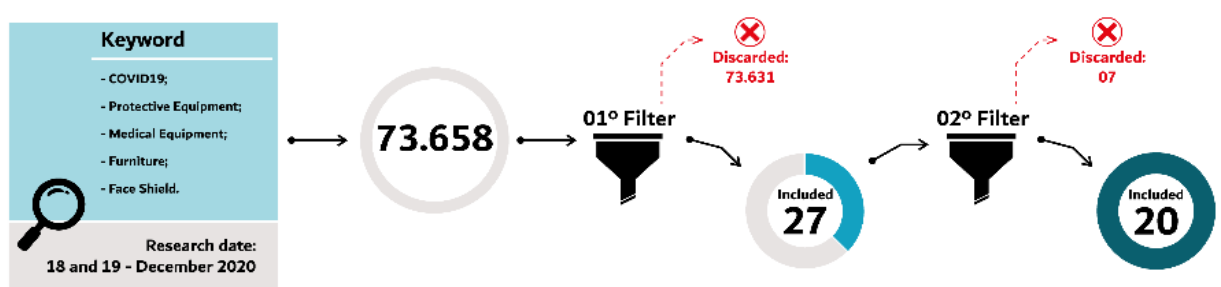

Figure 4. Document filtering process. Source: Author's elaboration (2020).

Table 2 presents the list of the 20 patents filed in 2020 which meet the research aims. The items were divided into the number of the registration process at the INPI, the title of the document, the relationship with the inventor's name, the identification of the person/institution responsible for the deposit and origin, this information was extracted from the documents accessed at the INPI. Furthermore, the items of academic background and Product Class was included by the researchers.

Table 2. Patent filed in 2020 .

\begin{tabular}{|c|c|c|c|c|c|c|c|}
\hline & Process & Title & Product Class & Depositor & Origin & Inventors & $\begin{array}{c}\text { Academic } \\
\text { background }\end{array}$ \\
\hline 01 & $\begin{array}{l}\mathrm{Br} 1020200 \\
13564-3 \mathrm{a} 3\end{array}$ & $\begin{array}{l}\text { Decontamination lockers for } \\
\text { changing rooms with uv-c light } \\
\text { and ozone }\end{array}$ & Furniture & $\begin{array}{l}\text { Rui Manuel Dias } \\
\text { Ferreira (Person) }\end{array}$ & Portugal & $\begin{array}{l}\text { Rui Manuel Dias } \\
\text { Ferreira }\end{array}$ & Civil engineer \\
\hline \multirow{3}{*}{02} & \multirow{3}{*}{$\begin{array}{l}\mathrm{Br} 1020200 \\
10670-8 \mathrm{a} 3\end{array}$} & \multirow{3}{*}{$\begin{array}{l}\text { Endotracheal tube support and } \\
\text { fixation device, nasogastric } \\
\text { tubes, enteral tubes and } \\
\text { sengstaken-blakemore balloon } \\
\text { with adjustable spring traction }\end{array}$} & \multirow{3}{*}{$\begin{array}{l}\text { Medical } \\
\text { equipment }\end{array}$} & \multirow{3}{*}{$\begin{array}{c}\text { Fundação } \\
\text { Educacional } \\
\text { Severino Sombra } \\
\text { (Private Institution) }\end{array}$} & \multirow{3}{*}{$\begin{array}{l}\text { Rio De } \\
\text { Janeiro }\end{array}$} & $\begin{array}{l}\text { Adauri Silveira } \\
\text { Rodrigues Júnior }\end{array}$ & $\begin{array}{l}\text { Mechanic } \\
\text { engineer }\end{array}$ \\
\hline & & & & & & $\begin{array}{c}\text { Eduardo Tavares Lima } \\
\text { Trajano }\end{array}$ & Physiotherapy \\
\hline & & & & & & $\begin{array}{l}\text { Cristina Maria } \\
\text { Monteiro Dantas }\end{array}$ & Medicine \\
\hline \multirow{5}{*}{03} & \multirow{5}{*}{$\begin{array}{c}\mathrm{Br} \\
202020008061- \\
5 \mathrm{u} 3\end{array}$} & \multirow{5}{*}{$\begin{array}{l}\text { Low cost autoclavable video } \\
\text { laryngoscope with barrier } \\
\text { device against aerosols and } \\
\text { respiratory droplets }\end{array}$} & \multirow{5}{*}{$\begin{array}{c}\text { Medical } \\
\text { equipment } \\
\text { (Laryngoscope) }\end{array}$} & \multirow{5}{*}{$\begin{array}{c}\text { Nely Marjollie } \\
\text { Guanabara Teixeira } \\
\text { Reis (Person) }\end{array}$} & \multirow{5}{*}{ Ceará } & $\begin{array}{c}\text { Nely Marjollie } \\
\text { Guanabara Teixeira } \\
\text { Reis }\end{array}$ & Medicine \\
\hline & & & & & & $\begin{array}{l}\text { Ivelise Regina Canito } \\
\text { Brasil }\end{array}$ & Medicine \\
\hline & & & & & & $\begin{array}{l}\text { David Silveira } \\
\text { Marinho }\end{array}$ & Medicine \\
\hline & & & & & & $\begin{array}{c}\text { Francisco Sales Ávila } \\
\text { Cavalcante }\end{array}$ & Physic \\
\hline & & & & & & $\begin{array}{l}\text { Thiago Ayres Barreira } \\
\text { De Campos Barros }\end{array}$ & $\begin{array}{c}\text { Social } \\
\text { Communications }\end{array}$ \\
\hline 04 & $\begin{array}{c}\mathrm{Br} \\
202020007905- \\
6 \mathrm{u} 3\end{array}$ & $\begin{array}{l}\text { Mattress with head support and } \\
\text { foot fitting }\end{array}$ & Furniture & $\begin{array}{l}\text { Eliézer Da Silva } \\
\text { Leite (Person) }\end{array}$ & Rondônia & Eliézer Da Silva Leite & $\begin{array}{l}\text { Without } \\
\text { information }\end{array}$ \\
\hline 05 & $\begin{array}{c}\mathrm{Br} \\
102020007474- \\
1 \mathrm{a} 2\end{array}$ & Decontamination cabinet & Furniture & $\begin{array}{l}\text { Rui Manuel Dias } \\
\text { Ferreira (Person) }\end{array}$ & Portugal & $\begin{array}{l}\text { Rui Manuel Dias } \\
\text { Ferreira }\end{array}$ & Civil engineer \\
\hline 06 & $\begin{array}{c}\mathrm{Br} \\
102020007226- \\
9 \mathrm{a} 2\end{array}$ & $\begin{array}{l}\text { Disposable stethoscope } \\
\text { protector }\end{array}$ & $\begin{array}{l}\text { Medical } \\
\text { equipment }\end{array}$ & $\begin{array}{l}\text { Flávio Alexandre } \\
\text { Soares (Person) }\end{array}$ & Góias & $\begin{array}{l}\text { Flávio Alexandre } \\
\text { Soares }\end{array}$ & Medicine \\
\hline 07 & $\begin{array}{c}\mathrm{Br} \\
102020006935- \\
7 \mathrm{a} 2\end{array}$ & Decontamination Portal & Furniture & $\begin{array}{l}\text { Rui Manuel Dias } \\
\text { Ferreira (Person) }\end{array}$ & Portugal & $\begin{array}{l}\text { Rui Manuel Dias } \\
\text { Ferreira }\end{array}$ & Civil engineer \\
\hline
\end{tabular}


Table 2. Continued...

\begin{tabular}{|c|c|c|c|c|c|c|c|}
\hline & Process & Title & Product Class & Depositor & Origin & Inventors & $\begin{array}{c}\text { Academic } \\
\text { background }\end{array}$ \\
\hline 08 & $\begin{array}{c}\mathrm{Br} \\
102020010492- \\
6 \text { a3 }\end{array}$ & $\begin{array}{l}\text { Antimicrobial decontamination } \\
\text { chamber }\end{array}$ & Furniture & $\begin{array}{l}\text { Jean José Clini } \\
\text { (Person) }\end{array}$ & $\begin{array}{l}\text { Mato } \\
\text { Grosso }\end{array}$ & Jean José Clini & Lawyer \\
\hline 09 & $\begin{array}{c}\mathrm{Br} \\
102020009195- \\
6 \mathrm{a} 2\end{array}$ & $\begin{array}{l}\text { Sensor module and universal } \\
\text { adapter for fluid dispensers }\end{array}$ & $\begin{array}{l}\text { Medical } \\
\text { equipment }\end{array}$ & $\begin{array}{l}\text { Muriel De Almeida } \\
\text { Ornela (Person) }\end{array}$ & $\begin{array}{l}\text { Minas } \\
\text { Gerais }\end{array}$ & $\begin{array}{l}\text { Muriel De Almeida } \\
\text { Ornela }\end{array}$ & Administration \\
\hline 10 & $\begin{array}{c}\mathrm{Br} \\
202020016707- \\
9 \text { u2 }\end{array}$ & $\begin{array}{l}\text { Arrangement introduced in face } \\
\text { protection mask with } \\
\text { transparent lens and ear support }\end{array}$ & Face shield & $\begin{array}{l}\text { Uni Máscaras } \\
\text { Comércio De } \\
\text { Máscaras Ltda - Me. } \\
\text { (Private Institution) }\end{array}$ & $\begin{array}{l}\text { Rio Grande } \\
\text { Do Sul }\end{array}$ & $\begin{array}{c}\text { Clara Maria Bonfante } \\
\text { Pereira }\end{array}$ & $\begin{array}{l}\text { Without } \\
\text { information }\end{array}$ \\
\hline \multirow{8}{*}{11} & & & & & & Antônio Fontana & $\begin{array}{l}\text { Without } \\
\text { information }\end{array}$ \\
\hline & & & & & & $\begin{array}{l}\text { Djalma Antonio } \\
\text { Chinaglia }\end{array}$ & $\begin{array}{l}\text { Without } \\
\text { information }\end{array}$ \\
\hline & & $\begin{array}{l}\text { Portable device attachable to } \\
\text { breathing mask or face protection }\end{array}$ & & & & $\begin{array}{l}\text { Nelson Maurici } \\
\text { Antônio }\end{array}$ & $\begin{array}{l}\text { Without } \\
\text { information }\end{array}$ \\
\hline & $\begin{array}{c}\mathrm{Br} \\
102020010046-\end{array}$ & $\begin{array}{l}\text { helmet for air sterilization for } \\
\text { breathing in environments }\end{array}$ & Face shield - & Opto Eletrônica S/A & São Paulo & Mario Antonio Stefani & $\begin{array}{l}\text { Mechanical } \\
\text { engineering }\end{array}$ \\
\hline & & $\begin{array}{l}\text { susceptible to contamination by } \\
\text { germs and viruses }\end{array}$ & & & & $\begin{array}{c}\text { Alessandre Rodrigues } \\
\text { Geraldo }\end{array}$ & $\begin{array}{c}\text { Electric } \\
\text { engineering }\end{array}$ \\
\hline & & & & & & $\begin{array}{l}\text { Gabriel Augusto } \\
\text { Tavares }\end{array}$ & Biologics \\
\hline & & & & & & Luiz Carlos Otoboni & Medicine \\
\hline & & & & & & Patricia Pires Otoboni & $\begin{array}{l}\text { Without } \\
\text { information }\end{array}$ \\
\hline 12 & $\begin{array}{c}\mathrm{Br} \\
102020009222- \\
7 \mathrm{a} 2\end{array}$ & Bipartite multilayer face mask & Face shield & $\begin{array}{l}\text { Malu Indústria E } \\
\text { Comércio De } \\
\text { Confeccoes Eireli Me. } \\
\text { (Private Institution) }\end{array}$ & $\begin{array}{c}\text { Santa } \\
\text { Catarina }\end{array}$ & $\begin{array}{l}\text { Sidemar Roberto } \\
\text { Ribeiro }\end{array}$ & $\begin{array}{l}\text { Control and } \\
\text { Automation } \\
\text { Engineering }\end{array}$ \\
\hline 13 & $\begin{array}{c}\mathrm{Br} \\
102020011320- \\
8 \mathrm{a} 2\end{array}$ & $\begin{array}{l}\text { Improvements introduced in } \\
\text { respiratory protection mask } \\
\text { with adjustable nose clip }\end{array}$ & Face shield & $\begin{array}{l}\text { Rcx Investimentos, } \\
\text { Tecnologia E Meios } \\
\text { De Pagamento Ltda } \\
\text { (Private Institution) }\end{array}$ & São Paulo & Ricardo Stradiotto & Physiotherapy \\
\hline 14 & $\begin{array}{c}\mathrm{Br} \\
202020009809- \\
3 \text { u2 }\end{array}$ & $\begin{array}{l}\text { Arrangement introduced in a } \\
\text { respiratory protection mask with } \\
\text { controlled physiological pressure } \\
\text { powered by an air compressor }\end{array}$ & Face shield & $\begin{array}{l}\text { José Custódio Feres } \\
\text { Vieira (Person) }\end{array}$ & São Paulo & $\begin{array}{c}\text { José Custódio Feres } \\
\text { Vieira }\end{array}$ & Dentist \\
\hline \multirow{7}{*}{15} & & & & & & $\begin{array}{l}\text { Luiz Fernando Da } \\
\text { Silva Borges }\end{array}$ & $\begin{array}{l}\text { Mecatronic } \\
\text { engineer }\end{array}$ \\
\hline & & & & & & Juliano Nehme Nassar & $\begin{array}{l}\text { Mecatronic } \\
\text { engineer }\end{array}$ \\
\hline & & & & Leventronic & & Guilherme Biazi Sabin & $\begin{array}{l}\text { Electronics } \\
\text { Technician }\end{array}$ \\
\hline & Br 102020 & Emergency and transient & Medical & $\begin{array}{l}\text { Tecnologia e Inovação } \\
\text { em Produtos para }\end{array}$ & $\begin{array}{c}\text { Mato } \\
\text { Grosso Do }\end{array}$ & Deise Ferreira Nantes & Medicine \\
\hline & & & & $\begin{array}{l}\text { Saúde Ltda (Private } \\
\text { Institution) }\end{array}$ & Sul & $\begin{array}{l}\text { Tiago Torminato } \\
\text { Moreira }\end{array}$ & Medicine \\
\hline & & & & & & Jader Lucas Perez & $\begin{array}{l}\text { Electrical } \\
\text { engineering }\end{array}$ \\
\hline & & & & & & $\begin{array}{c}\text { Daniel Augusto Dias } \\
\text { Araujo }\end{array}$ & $\begin{array}{l}\text { Control and } \\
\text { Automation } \\
\text { Engineering }\end{array}$ \\
\hline 16 & $\begin{array}{c}\mathrm{Br} \\
202020009933- \\
2 \text { u2 }\end{array}$ & $\begin{array}{l}\text { Constructive arrangement } \\
\text { introduced in protective mask }\end{array}$ & Face shield & $\begin{array}{l}\text { Rafael Ricardo Do } \\
\text { Carmo (Person) }\end{array}$ & $\begin{array}{l}\text { Rio De } \\
\text { Janeiro }\end{array}$ & $\begin{array}{c}\text { Rafael Ricardo Do } \\
\text { Carmo }\end{array}$ & Lawyer \\
\hline \multirow{7}{*}{17} & \multirow{7}{*}{$\begin{array}{c}\mathrm{Br} \\
102020014712- \\
9 \mathrm{a} 2\end{array}$} & \multirow{7}{*}{$\begin{array}{l}\text { Capsule for use during airway } \\
\text { management }\end{array}$} & \multirow{7}{*}{$\begin{array}{c}\text { Equipment } \\
\text { protection } \\
\text { (Intubation Box) }\end{array}$} & \multirow{7}{*}{$\begin{array}{l}\text { Universidade Federal } \\
\text { De Viçosa (Public } \\
\text { Educational Institution) }\end{array}$} & \multirow{7}{*}{$\begin{array}{l}\text { Minas } \\
\text { Gerais }\end{array}$} & Andréia Guerra Siman & Nursing \\
\hline & & & & & & $\begin{array}{l}\text { Alexandre Santos } \\
\text { Brandão }\end{array}$ & Lawyer \\
\hline & & & & & & $\begin{array}{c}\text { Flávia Batista Barbosa } \\
\text { De Sá Diaz }\end{array}$ & Nursing \\
\hline & & & & & & $\begin{array}{l}\text { André Teixeira Da } \\
\text { Costa }\end{array}$ & $\begin{array}{l}\text { Architecture and } \\
\text { urbanism }\end{array}$ \\
\hline & & & & & & $\begin{array}{l}\text { Celso Oliveira } \\
\text { Barcelos }\end{array}$ & $\begin{array}{l}\text { Electrical } \\
\text { engineering }\end{array}$ \\
\hline & & & & & & $\begin{array}{l}\text { Vinicius Resende De } \\
\text { Castro }\end{array}$ & $\begin{array}{c}\text { Forest } \\
\text { engineering }\end{array}$ \\
\hline & & & & & & $\begin{array}{c}\text { Leonardo Fenyves } \\
\text { Ferreira }\end{array}$ & Medicine \\
\hline
\end{tabular}


Table 2. Continued...

\begin{tabular}{|c|c|c|c|c|c|c|c|}
\hline & Process & Title & Product Class & Depositor & Origin & Inventors & $\begin{array}{c}\text { Academic } \\
\text { background }\end{array}$ \\
\hline 18 & $\begin{array}{c}\mathrm{Br} \\
202020008584- \\
6 \text { u2 }\end{array}$ & $\begin{array}{l}\text { Provision introduced in } \\
\text { protective mask }\end{array}$ & Face shield & $\begin{array}{l}\text { Claudio Luiz } \\
\text { Teixeira Junior } \\
\text { (Person) }\end{array}$ & São Paulo & $\begin{array}{l}\text { Claudio Luiz Teixeira } \\
\text { Junior }\end{array}$ & Marketing \\
\hline 19 & $\begin{array}{c}\mathrm{Br} \\
202020008493- \\
9 \mathrm{u} 2\end{array}$ & $\begin{array}{l}\text { Instrument for suction of the } \\
\text { aerosol resulting in dental } \\
\text { procedures used in connection } \\
\text { with the vacuum pump, suction } \\
\text { pump, sucker or any type of } \\
\text { independent vacuum cleaner }\end{array}$ & $\begin{array}{l}\text { Medical } \\
\text { equipment - } \\
\text { dental }\end{array}$ & $\begin{array}{l}\text { Jean Cristian } \\
\text { Benkenstein } \\
\text { (Person) }\end{array}$ & $\begin{array}{l}\text { Rio Grande } \\
\text { Do Sul }\end{array}$ & $\begin{array}{l}\text { Jean Cristian } \\
\text { Benkenstein }\end{array}$ & $\begin{array}{l}\text { Mechanical } \\
\text { technician }\end{array}$ \\
\hline 20 & $\begin{array}{c}\mathrm{Br} \\
202020007462- \\
3 \mathrm{u} 2\end{array}$ & $\begin{array}{l}\text { Arrangement introduced in } \\
\text { protective adhesive film }\end{array}$ & $\begin{array}{l}\text { Equipment } \\
\text { protection } \\
\text { (Gloves) }\end{array}$ & $\begin{array}{l}\text { Sulamita Caroline } \\
\text { Melo De França } \\
\text { Guedes (Person) }\end{array}$ & $\begin{array}{l}\text { Rio De } \\
\text { Janeiro }\end{array}$ & $\begin{array}{l}\text { Sulamita Caroline } \\
\text { Melo De França } \\
\text { Guedes }\end{array}$ & $\begin{array}{l}\text { Without } \\
\text { information }\end{array}$ \\
\hline
\end{tabular}

Source: Author's elaboration (2020).

Analyzing the classes of products that were patented, Figure 5 shows the predominance of Facial Protectors, with a total of $35 \%$, representing 7 registrations, and the diversity of depositors. Furniture accounts for $25 \%$, totaling 5 registrations in this class of products, including those from decontamination portals to internal or external cabinets, and regarding the depositors, Rui Manuel Dias Ferreira stands out with 3 registrations. Medical equipment had 5 records ( $25 \%$ of the total), however, the tab with emphasis on dentistry was tabulated separately, due to the exclusivity of use and the nature of the activity, as the other records have different characteristics. In addition to these, it was possible to observe the presence of 1 record for Laryngoscope, 1 for intubation box under the title "Capsule for use during airway management", and 1 for protective gloves.

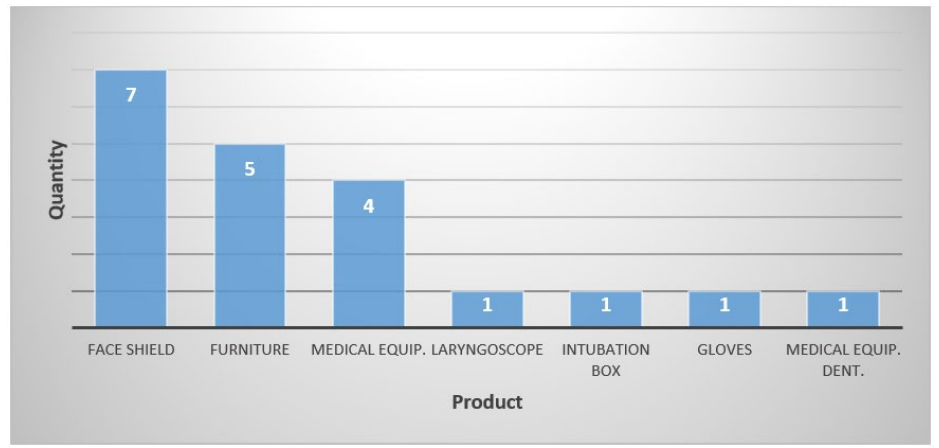

Figure 5. Product class overview. Source: Author's elaboration (2020).

To understand the nature of the depositors, Figure 6 was elaborated, in which the predominance is of individual depositors, with 13 records, representing $65 \%$ of the total. Soon after, private institutions filed 5 patents, which represents $25 \%$, and educational institutions filed 2 records, one from a private institution and the other from a public institution.

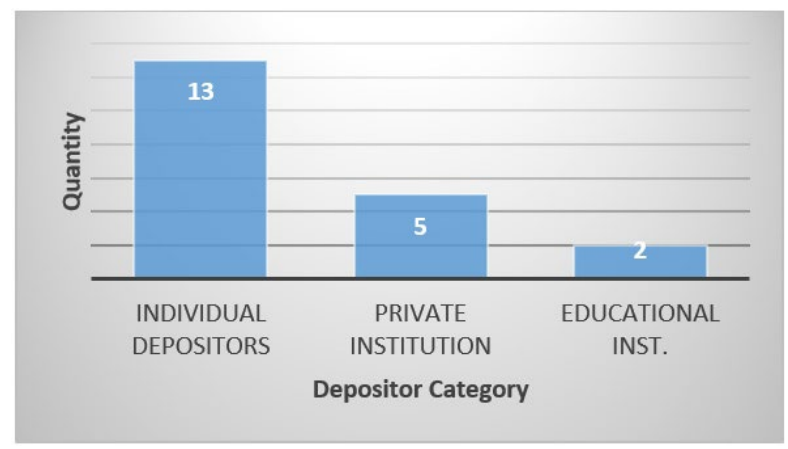

Figure 6. Depositor category. Source: Author's elaboration (2020).

In Figure 7, the academic background of the inventors are presented. Among the 45 inventors that composed the sample, the search identified the academic background of $86.4 \%$ of them, while the information of the other $13.6 \%$ (6 inventors) was not found. It was found that 29.5\% (14 inventors) are from the area of Health Sciences 
and $27.1 \%$ (12 inventors) from the area of Engineering, and the rest are distributed in different areas and technical courses, such as mechanics and electronics.

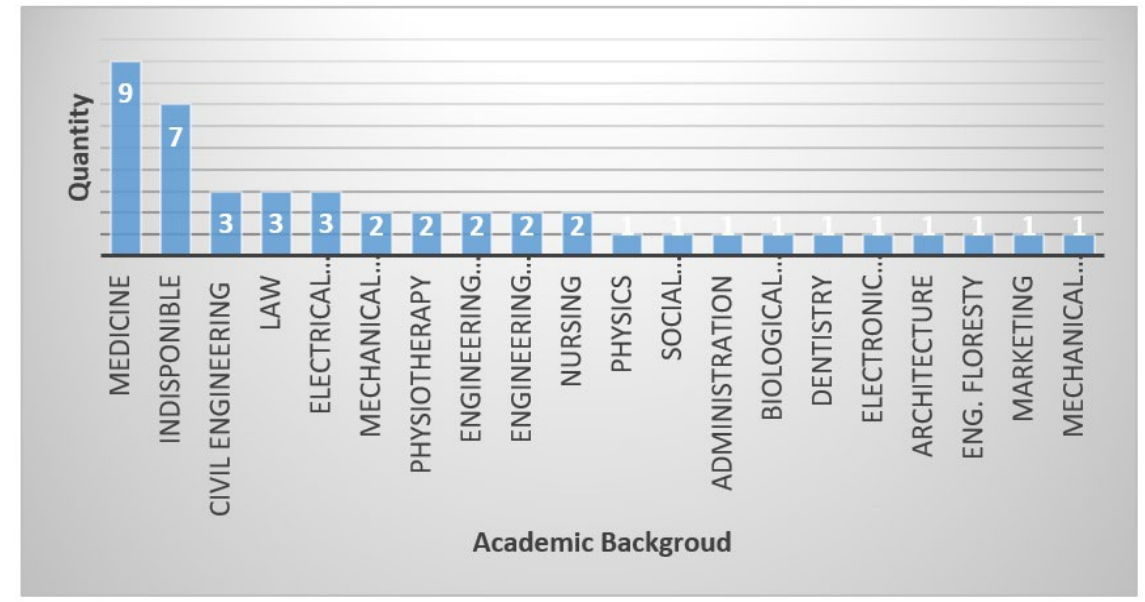

Figure 7. Inventor's academic background. Source: Author's elaboration (2020).

Regarding the origin of the patents, as shown in Figure 8, it was identified 1 application from the State of Ceará in the Northeast region; 1 in the State of Rondônia, in the North region; 3 from the Midwest region, with 1 for each State (Goiás, Mato Grosso and Mato Grosso do Sul); 3 from the South region, with 2 in Rio Grande do Sul and 1 in Santa Catarina; and 9 from the Southeast region, 4 from São Paulo, 3 from Rio de Janeiro and 2 from Minas Gerais. In addition, 3 requests from outside of the country were identified, specifically from Portugal.

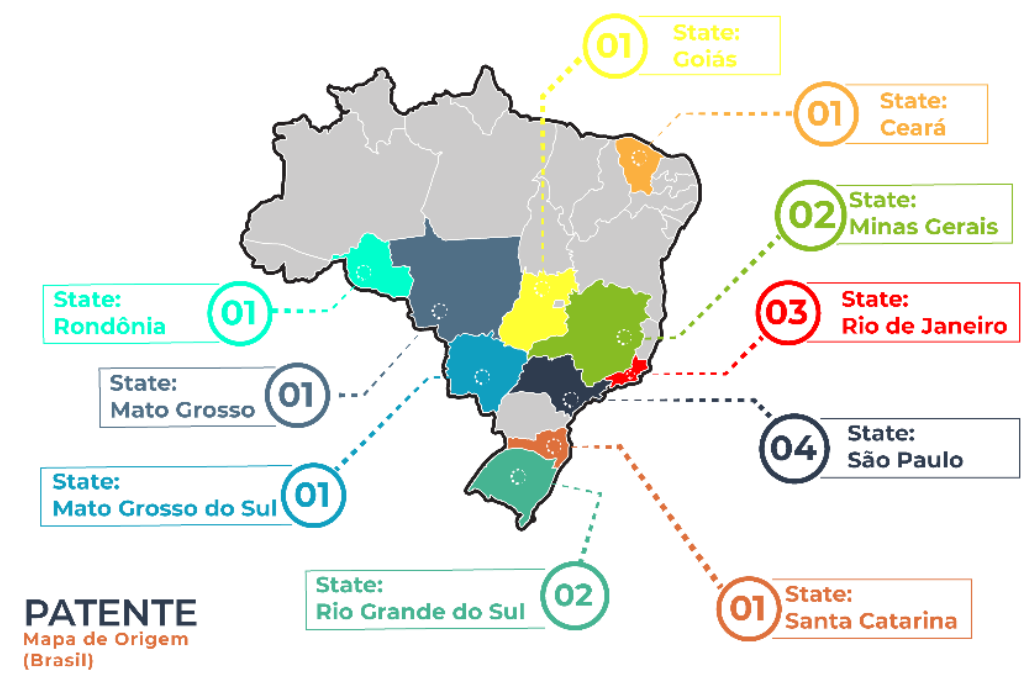

Figure 8. Origin of patent applications according to the Brazil Map. Source: Author's elaboration (2020).

\subsection{Industrial design}

The industrial design survey in the INPI database was carried out between 21 and 22 December 2020 and returned a total of 6710 documents. Removing duplicates, based on the first filter criteria, 43 documents remained for the second filter, and 22 documents remained for data synthesis and cataloging, through a visual panel. Figure 9 shows the document filtering process.

Table 3 presents the list of the 22 industrial designs deposited in the year of 2020 which meet the research aims. 


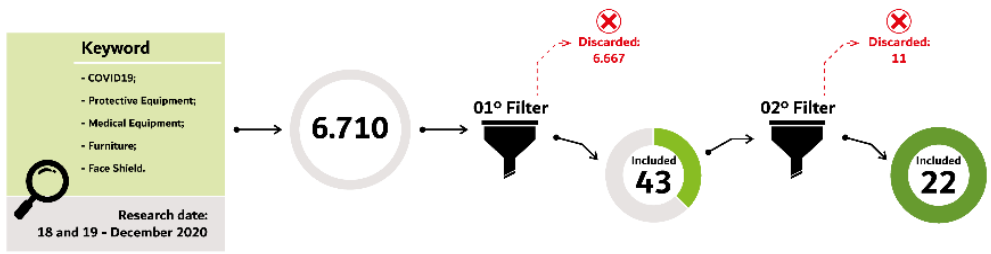

Figure 9. Document filtering process. Source: Author's elaboration (2020).

Table 3. Industrial designs deposited in 2020.

\begin{tabular}{|c|c|c|c|c|c|c|c|}
\hline & Process & Title & Product Class & Titular & Origin & Inventor(a) & $\begin{array}{c}\text { Academic } \\
\text { background }\end{array}$ \\
\hline \multirow{5}{*}{01} & \multirow{5}{*}{$\begin{array}{c}\mathrm{Br} \\
302020003797-9\end{array}$} & \multirow{5}{*}{$\begin{array}{l}\text { Configuration Applied } \\
\text { To / In Face Protector }\end{array}$} & \multirow{5}{*}{ Face Protector } & \multirow{5}{*}{$\begin{array}{l}\text { Universidade Federal } \\
\text { De Santa Catarina } \\
\text { (Public Educational } \\
\text { Institution) }\end{array}$} & \multirow{5}{*}{$\begin{array}{c}\text { Santa } \\
\text { Catarina }\end{array}$} & $\begin{array}{c}\text { Eugenio Andrés Díaz } \\
\text { Merino }\end{array}$ & Design \\
\hline & & & & & & $\begin{array}{l}\text { Giselle Schmidt } \\
\text { Alves Díaz Merino }\end{array}$ & Design \\
\hline & & & & & & Diogo Pontes Costa & Design \\
\hline & & & & & & Cesar Nunes Giracca & $\begin{array}{l}\text { Biomedical } \\
\text { engineering }\end{array}$ \\
\hline & & & & & & $\begin{array}{l}\text { Felipe Lopes } \\
\text { Machado }\end{array}$ & Biology \\
\hline \multirow{5}{*}{02} & \multirow{5}{*}{$\begin{array}{c}\mathrm{Br} \\
302020003798-7\end{array}$} & \multirow{5}{*}{$\begin{array}{l}\text { Configuration Applied } \\
\text { To / In Face Protector }\end{array}$} & \multirow{5}{*}{ Face Protector } & \multirow{5}{*}{$\begin{array}{l}\text { Universidade Federal } \\
\text { De Santa Catarina } \\
\text { (Public Educational } \\
\text { Institution) }\end{array}$} & \multirow{5}{*}{$\begin{array}{c}\text { Santa } \\
\text { Catarina }\end{array}$} & $\begin{array}{l}\text { Eugenio Andrés Díaz } \\
\text { Merino }\end{array}$ & Design \\
\hline & & & & & & $\begin{array}{l}\text { Giselle Schmidt } \\
\text { Alves Díaz Merino }\end{array}$ & Design \\
\hline & & & & & & Diogo Pontes Costa & Design \\
\hline & & & & & & Cesar Nunes Giracca & $\begin{array}{l}\text { Biomedical } \\
\text { engineering }\end{array}$ \\
\hline & & & & & & $\begin{array}{l}\text { Felipe Lopes } \\
\text { Machado }\end{array}$ & Biology \\
\hline 03 & $\begin{array}{c}\mathrm{Br} \\
302020002408-7\end{array}$ & $\begin{array}{l}\text { Configuration Applied } \\
\text { To / In Face Protector }\end{array}$ & Face Protector & $\begin{array}{l}\text { Agatha Hwan } \\
\text { (Person) }\end{array}$ & São Paulo & Agatha Hwan & $\begin{array}{l}\text { Without } \\
\text { information }\end{array}$ \\
\hline \multirow{3}{*}{04} & \multirow{3}{*}{$\begin{array}{c}\mathrm{Br} \\
302020002259-9\end{array}$} & \multirow{3}{*}{$\begin{array}{l}\text { Configuration Applied } \\
\text { To / In Face Protector }\end{array}$} & \multirow{3}{*}{ Face Protector } & \multirow{3}{*}{$\begin{array}{l}\text { Universidade Federal } \\
\text { De Juiz De Fora } \\
\text { (Public Educational } \\
\text { Institution) }\end{array}$} & \multirow{3}{*}{$\begin{array}{l}\text { Minas } \\
\text { Gerais }\end{array}$} & $\begin{array}{c}\text { Paulo Miranda De } \\
\text { Oliveira }\end{array}$ & Design \\
\hline & & & & & & Róber Dias Botelho & Product Design \\
\hline & & & & & & $\begin{array}{l}\text { André Carvalho Mol } \\
\text { Silva }\end{array}$ & Design \\
\hline 05 & $\begin{array}{c}\mathrm{Br} 302020 \\
0020863\end{array}$ & $\begin{array}{l}\text { Configuration Applied } \\
\text { To / In Face Protector }\end{array}$ & Face Protector & $\begin{array}{l}\text { Evandro Da Silva } \\
\text { Nicola (Person) } \\
\text { Mirella Frapiccini } \\
\text { Nicolle (Person) }\end{array}$ & $\begin{array}{c}\text { Santa } \\
\text { Catarina }\end{array}$ & $\begin{array}{c}\text { Evandro Da Silva } \\
\text { Nicola }\end{array}$ & $\begin{array}{l}\text { Without } \\
\text { information }\end{array}$ \\
\hline 06 & $\begin{array}{c}\mathrm{Br} \\
302020002061-8\end{array}$ & $\begin{array}{l}\text { Configuration Applied } \\
\text { To / In Face Protector }\end{array}$ & Face Protector & $\begin{array}{c}\text { Adriano José } \\
\text { Nogueira (Person) }\end{array}$ & São Paulo & $\begin{array}{l}\text { Adriano José } \\
\text { Nogueira }\end{array}$ & $\begin{array}{l}\text { Without } \\
\text { information }\end{array}$ \\
\hline 07 & $\begin{array}{c}\mathrm{Br} \\
302020002022-7\end{array}$ & $\begin{array}{l}\text { Configuration Applied } \\
\text { To / In Face Protector }\end{array}$ & Face Protector & $\begin{array}{l}\text { Santa Proteção } \\
\text { Fabricação E } \\
\text { Comércio De } \\
\text { Máscaras Para Uso } \\
\text { Hospitalar Ltda } \\
\text { (Private Inst.) }\end{array}$ & São Paulo & Carla Diana Galiassi & Dentist \\
\hline 08 & $\begin{array}{c}\mathrm{Br} \\
302020003837-1\end{array}$ & $\begin{array}{c}\text { Configuration Applied } \\
\text { To / In Facial Mask For } \\
\text { Dentistry }\end{array}$ & Face Protector & $\begin{array}{l}\text { Marcelo Sanmartin } \\
\text { De Almeida (Person) }\end{array}$ & $\begin{array}{l}\text { Rio De } \\
\text { Janeiro }\end{array}$ & $\begin{array}{l}\text { Marcelo Sanmartin } \\
\text { De Almeida }\end{array}$ & Dentist \\
\hline 09 & $\begin{array}{c}\mathrm{Br} \\
302020003247-0\end{array}$ & $\begin{array}{l}\text { Configuration Applied } \\
\text { To / In Face Mask }\end{array}$ & Face Protector & $\begin{array}{l}\text { Guilherme Alves De } \\
\text { Azevedo (Person) }\end{array}$ & Ceará & $\begin{array}{c}\text { Guilherme Alves De } \\
\text { Azevedo }\end{array}$ & Civil engineer \\
\hline 10 & $\begin{array}{c}\mathrm{Br} \\
302020002602-0\end{array}$ & $\begin{array}{c}\text { Configuration Applied } \\
\text { To / In Face Mask Tie } \\
\text { Clasp }\end{array}$ & Face Protector & $\begin{array}{l}\text { Patrícia Pereira } \\
\quad \text { (Person) }\end{array}$ & $\begin{array}{c}\text { Santa } \\
\text { Catarina }\end{array}$ & Patrícia Pereira & $\begin{array}{l}\text { Without } \\
\text { information }\end{array}$ \\
\hline 11 & $\begin{array}{c}\mathrm{Br} \\
302020002384-6\end{array}$ & $\begin{array}{c}\text { Configuration Applied } \\
\text { To / In Face Protection } \\
\text { Mask }\end{array}$ & Face Protector & Jucimar Piva (Person) & $\begin{array}{c}\text { Santa } \\
\text { Catarina }\end{array}$ & Jucimar Piva & $\begin{array}{l}\text { Without } \\
\text { information }\end{array}$ \\
\hline 12 & $\begin{array}{c}\mathrm{Br} \\
302020001806-0\end{array}$ & $\begin{array}{c}\text { Configuration Applied } \\
\text { To / In Face Protection } \\
\text { Mask }\end{array}$ & Face Protector & $\begin{array}{l}\text { Extramold Jomo } \\
\text { Indústria De Plásticos } \\
\text { Ltd. (Private Inst.) }\end{array}$ & $\begin{array}{l}\text { Rio Grande } \\
\text { Do Sul }\end{array}$ & $\begin{array}{l}\text { Dagmar Luise } \\
\text { Mohrbach }\end{array}$ & Administration \\
\hline
\end{tabular}


Table 3. Continued...

\begin{tabular}{|c|c|c|c|c|c|c|c|}
\hline & Process & Title & Product Class & Titular & Origin & Inventor(a) & $\begin{array}{c}\text { Academic } \\
\text { background }\end{array}$ \\
\hline 13 & $\begin{array}{c}\mathrm{Br} \\
302020001765-0\end{array}$ & $\begin{array}{c}\text { Configuration Applied } \\
\text { To / In Protective Face } \\
\text { Mask }\end{array}$ & Face Protector & $\begin{array}{l}\text { Alexandre De Freitas } \\
\text { Miranda (Person) }\end{array}$ & $\begin{array}{l}\text { Rio De } \\
\text { Janeiro }\end{array}$ & $\begin{array}{c}\text { Alexandre De Freitas } \\
\text { Miranda }\end{array}$ & Medicine \\
\hline 14 & $\begin{array}{c}\mathrm{Br} \\
302020001642-4\end{array}$ & $\begin{array}{c}\text { Configuration Applied } \\
\text { To / In Face Protection } \\
\text { Mask }\end{array}$ & Face Protector & $\begin{array}{l}\text { Extramold Jomo } \\
\text { Indústria De Plásticos } \\
\text { Ltda (Private Inst.) }\end{array}$ & $\begin{array}{l}\text { Rio Grande } \\
\text { Do Sul }\end{array}$ & $\begin{array}{l}\text { Dagmar Luise } \\
\text { Mohrbach }\end{array}$ & Administration \\
\hline 15 & $\begin{array}{c}\mathrm{Br} \\
302020002958-5\end{array}$ & $\begin{array}{c}\text { Configuration Applied } \\
\text { To / In Goggles }\end{array}$ & Face Protector & $\begin{array}{l}\text { Ferramentaria } \\
\text { Matrimolde Ltda } \\
\text { (Private Inst.) }\end{array}$ & Paraná & $\begin{array}{l}\text { Eliane Marcelino } \\
\text { Rodrigues Goulart }\end{array}$ & \\
\hline 16 & $\begin{array}{c}\mathrm{Br} \\
302020002830-9\end{array}$ & $\begin{array}{l}\text { Configuration Applied } \\
\text { To / In Goggles }\end{array}$ & Face Protector & $\begin{array}{l}\text { Wjd Representações } \\
\text { E Participações Ltda. } \\
\text { (Private Inst.) }\end{array}$ & Paraná & $\begin{array}{c}\text { Wanderleia } \\
\text { Gonçalves Jentzsch }\end{array}$ & $\begin{array}{l}\text { Without } \\
\text { information }\end{array}$ \\
\hline 17 & $\begin{array}{c}\mathrm{Br} \\
302020002638-1\end{array}$ & $\begin{array}{l}\text { Configuration Applied } \\
\text { To / In Accessory for } \\
\text { Medical Equipment }\end{array}$ & $\begin{array}{l}\text { Medical } \\
\text { equipment }\end{array}$ & $\begin{array}{l}\text { Koninklijke Philips } \\
\text { N.V. (Inst. Privada) }\end{array}$ & - & Hao Hua & Design \\
\hline 18 & $\begin{array}{c}\mathrm{Br} \\
302020002626-8\end{array}$ & $\begin{array}{l}\text { Ornamental Pattern } \\
\text { Applied To / In } \\
\text { Graphical User } \\
\text { Interface for Medical } \\
\text { Equipment }\end{array}$ & Digital Interface & $\begin{array}{l}\text { Koninklijke Philips } \\
\text { N.V. (Private Inst.) }\end{array}$ & - & Hao Hua & Design \\
\hline 19 & $\begin{array}{c}\mathrm{Br} \\
302020002384-6\end{array}$ & $\begin{array}{c}\text { Configuration Applied } \\
\text { To / In Face Protection } \\
\text { Mask }\end{array}$ & Face Protector & Jucimar Piva (Person) & $\begin{array}{c}\text { Santa } \\
\text { Catarina }\end{array}$ & Jucimar Piva & $\begin{array}{l}\text { Without } \\
\text { information }\end{array}$ \\
\hline 20 & $\begin{array}{c}\mathrm{Br} \\
302020002351-0\end{array}$ & $\begin{array}{c}\text { Configuration Applied } \\
\text { To / In Face Protection } \\
\text { Mask }\end{array}$ & Face Protector & $\begin{array}{c}\text { Marcos Alexandre } \\
\text { Barros Rodrigues } \\
\text { (Person) }\end{array}$ & - & $\begin{array}{c}\text { Marcos Alexandre } \\
\text { Barros Rodrigues }\end{array}$ & $\begin{array}{l}\text { Without } \\
\text { information }\end{array}$ \\
\hline 21 & $\begin{array}{c}\mathrm{Br} \\
302020002348-0\end{array}$ & $\begin{array}{c}\text { Configuration Applied } \\
\text { To / In Face Protection } \\
\text { Mask }\end{array}$ & Face Protector & $\begin{array}{l}\text { Ezequiel Miqueias } \\
\text { Marques (Pessoa } \\
\text { Física) }\end{array}$ & São Paulo & $\begin{array}{l}\text { Ezequiel Miqueias } \\
\text { Marques }\end{array}$ & $\begin{array}{l}\text { Without } \\
\text { information }\end{array}$ \\
\hline \multirow{2}{*}{22} & \multirow{2}{*}{$\begin{array}{c}\mathrm{Br} \\
302020001896-6\end{array}$} & \multirow{2}{*}{$\begin{array}{l}\text { Configuration Applied } \\
\text { To / In Protection Mask }\end{array}$} & \multirow{2}{*}{ Face Protector } & \multirow{2}{*}{$\begin{array}{l}\text { Sulinject Ltda. } \\
\text { (Private Inst.) }\end{array}$} & \multirow{2}{*}{$\begin{array}{l}\text { Rio Grande } \\
\text { Do Sul }\end{array}$} & $\begin{array}{c}\text { Christian Thomas } \\
\text { Price }\end{array}$ & $\begin{array}{l}\text { Without } \\
\text { information }\end{array}$ \\
\hline & & & & & & $\begin{array}{l}\text { Daniel De Souza } \\
\text { Monteiro }\end{array}$ & $\begin{array}{l}\text { Production } \\
\text { engineer }\end{array}$ \\
\hline
\end{tabular}

Source: Author's elaboration (2020).

After the final records tabulation, it was noticed the prevalence of Facial Protection related products was noticed, since 20 records, which represents $90.9 \%$ of the total, were related to this class of products the other 2 records are part of a project from the Koninklijke Philips institution, one for the device and the other for its digital interface (Figure 10).

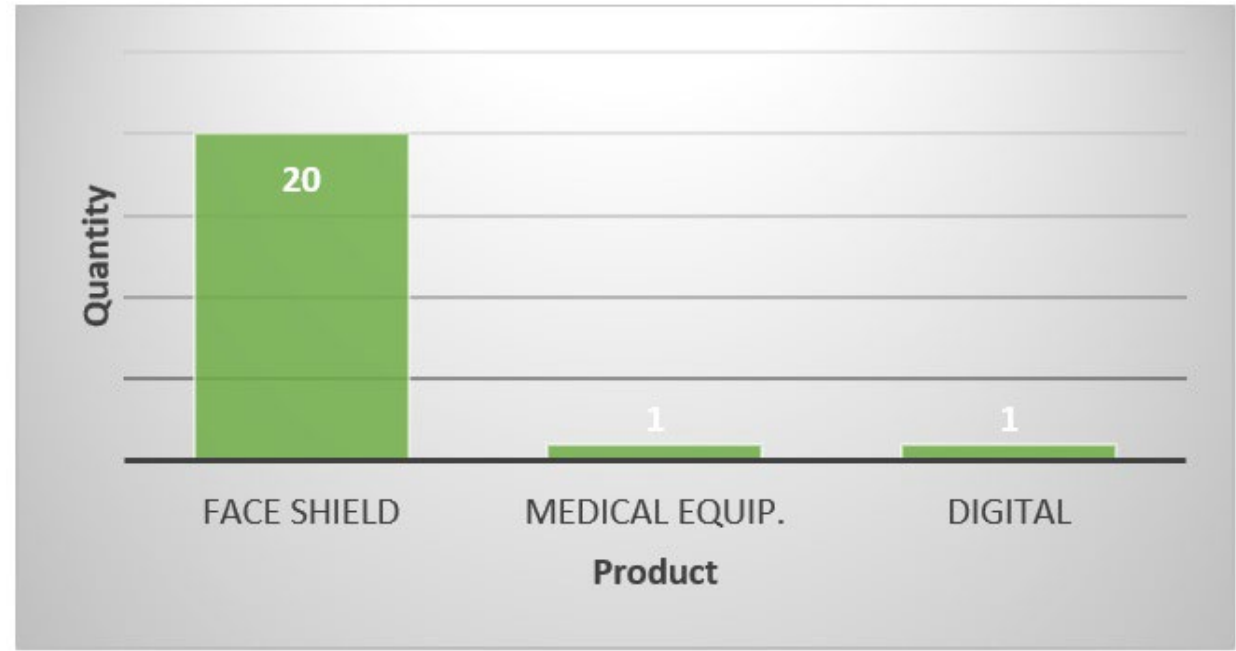

Figure 10. Product class overview. Source: Author's elaboration (2020).

Concerning the nature of the inventors, there is a predominance of records from individuals, with 11 in total, followed by 8 records from private institutions, and 3 from public educational institutions, in which 2 are from the Universidade Federal de Santa Catarina and 1 from the Universidade de Juiz de Fora (Figure 11). 


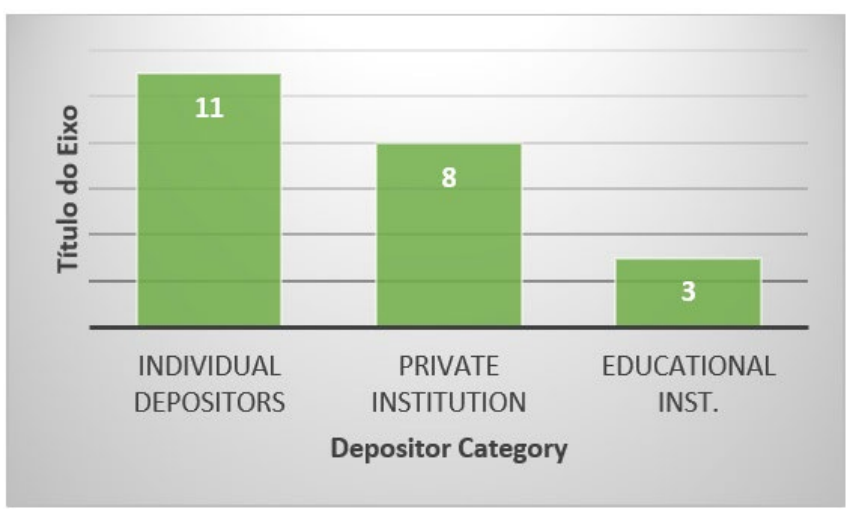

Figure 11. Depositors' category. Source: Author's elaboration (2020).

Regarding the inventor's academic background, the same pattern of searches for patents was followed. A total of 32 inventors were identified and accounted for, however, 10 of these did not present information on academic background. Of those identified, 10 are from the area of Design, representing $31.3 \%$ of the total. Four inventors are from the Engineering area and 3 from Health Sciences. In addition to these, there is 1 inventor for the Product Project, 2 from the area of Biology and 2 from Administration, as shown in Figure 12.

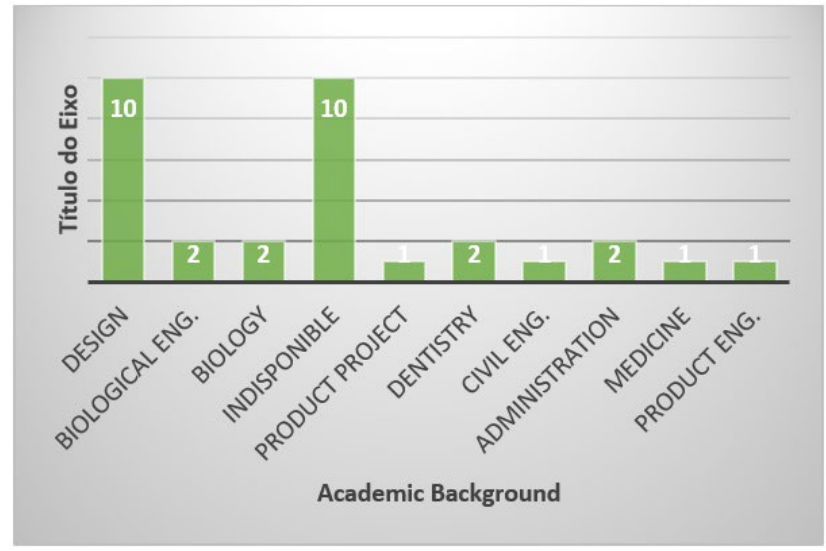

Figure 12. Inventor's academic background. Source: Author's elaboration (2020).

About the origin of the patents, as shown in Figure 13, 1 application was identified as being from the State of Ceará in the Northeast region; 11 from the South region, with 3 in Rio Grande do Sul, 2 in Paraná and 6 in Santa Catarina; and 7 from the Southeast, 4 from São Paulo, 2 from Rio de Janeiro and 1 from Minas Gerais. In addition, 3 requests were not identified.

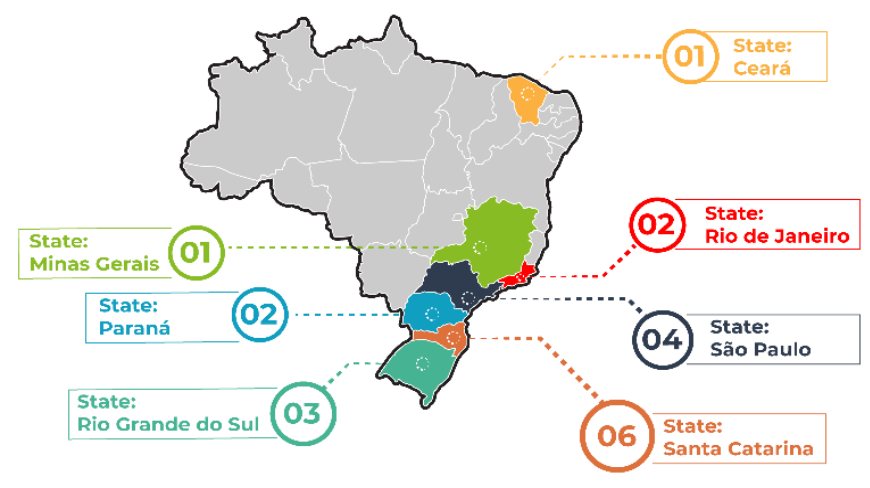

\section{INDUSTRIAL}

Figure 13. Origin of industrial design requests according to the Brazil map. Source: Author's elaboration (2020). 


\section{Discussion}

Regarding the classes of products, there is a predominance of projects related to facial protection, totaling $64.3 \%$, representing 27 projects. It is believed that this amount is related to the urgency, importance and scarcity of this product, and because it is easily materialized (Shokrani et al., 2020; Chu et al., 2020; Wang et al., 2020; Khan \& Parab, 2020).

Medical equipment, with 6 projects (14.3\%), represents another significant portion in the general quantity, followed by furniture, with 5 projects (11.9\%), and laryngoscope, gloves, and digital interface, with 1 project each. The increase of medical projects explained by COVID-19, which directed the focus of projects to the health area and boosted the growth of innovations (World Intellectual Property Organization, 2020).

Individuals with no declared link to any institution, at least according to the information documents presented to the INPI, were the ones that most submitted projects, totaling 24 , which represents $57.1 \%$ of the total. Private institutions concentrate a total of 13 projects $(31 \%)$, followed by public educational institutions, with 4 projects $(9.5 \%)$, and 1 project comes from a private educational institution.

These results are in agreement with the scientific literature. In Brazil, the impact of universities on the number of patents should be greater, and the innovation process has a strong association with private sector companies (Buainain \& Souza, 2018; Sichel, 2020). In addition, patent applications from non-residents in the country represent a large proportion of the applications made (Buainain \& Souza, 2018).

Innovation in Brazil aimed to bring together universities and companies. However, it did not present consistent policies for the most expensive phases, weakening this relationship (Oliveira \& Telles, 2011). Consequently, Brazilian companies have minimized the importance of cooperative relations with universities and research institutes (Bagattolli \& Dagnino, 2013).

In addition, ideological and economic changes in Brazil influence the motivation of researchers, as well as the purchasing power of the regions is reflected in public universities, accentuating inequalities in the capacity to produce patents. (Mueller \& Perucchi, 2014). These factors explain why the relationship between applying for and granting patents to universities is still low in the country.

Despite this, there are positive aspects. Government policies focused on innovation impact growth in $R \& D$ (Oliveira et al., 2015). Universities also benefited, as the financing strategies fostered research in several areas of knowledge, such as health (Uchoa et al., 2011). As a result, has been an increase in patent registration over the past twenty years (Oliveira \& Velho, 2010).

As for the academic background of inventors and the relationship with project, the presence of multidisciplinary projects stands out, such as the projects "capsule for use during airway management", "emergency and transient breathing support equipment", "Attachable portable device for breathing mask or face protection helmet for air sterilization for breathing in environments susceptible to contamination by germs and viruses", among others.

It is understood that the difficulty of identifying the inventor's academic background may have repercussions on the actual results, as in 18 cases $(23.4 \%)$ it was not possible to confirm the findings. There was a predominance of inventors from the areas of Engineering and Health Sciences, both with 17 inventors, representing $22.1 \%$ each. 10 inventors are graduates from a Design program, which represents $13 \%$ of the total, followed by other programs, which represent $19.5 \%$. Despite the multidisciplinarity presented in several projects, as addressed by Briede-Westermeyer et al. (2017), and the prevalence of the areas of Engineering, Health and Design, it was possible to identify the absence of projects that would bring this triad together.

About the origin of the projects, the regions with the most quantity of applications are the Southeast with 16 projects and the South with 14. The states of São Paulo and Santa Catarina have 8 and 7 registrations, respectively, followed by Rio Grande do Sul and Rio de Janeiro, each with 5. Paraná has 2 applications, and Minas Gerais 1. The Midwest region also registered 3 orders, 1 in each state (Goiás, Mato Grosso and Mato Grosso do Sul), while the Northeast region has 2 applications, both from the state of Ceará. In the North region, the only state that registered an order was Rondônia, with 1 request. In addition, 1 project has not had its origin identified and 5 are from holders and/or institutions headquartered outside the country.

These results show that the states with the strongest economy had a higher number of patent registrations This is a reflection of the inequalities that exist in this country, in which few states, such as São Paulo, Rio de Janeiro, Minas Gerais, Paraná, and Rio Grande do Sul, concentrate $70 \%$ of the total orders.

However, the direct relationship between the capacity for innovation and the economic conditions of the regions is global. The Global Innovation Index (IGI) showed that: (i) the strongest economies were global innovation leaders in the year 2020 and (ii) strong economies, represented by Switzerland, the United States, Germany, China, Japan and the Republic of Korea, were leaders in relation to patents by origin (World Intellectual Property Organization, 2009). 
Comparing Brazil with these countries, the indicators showed that the country did not follow the evolution that occurred in the area of innovation, increasing the distance in relation to developed countries and developing countries, such as China and South Korea (Buainain \& Souza, 2018).

Thus, due to the need for agility in the development of projects that seek to mitigate the problems arising from COVID-19, the search and review in the database of industrial property institutes, as is the case of INPI, becomes an action capable of bring efficiency to the process, since it is possible to identify which projects are being developed in the Brazilian scenario, as well as to contact the inventors to collect more in-depth information and, if desired from both parties, establish partnerships.

\section{Conclusions}

The purpose of this paper was to identify the Brazilian overview of applications for Utility Model Patents and Industrial Designs related to helping and protecting people from the new coronavirus of the Severe Acute Respiratory Syndrome (SARS-CoV-2), registered with the INPI. For this, the methodological procedures, which were based on six steps of the systematization proposed by Donato \& Donato (2019), proved to be satisfactory, as they allowed to achieve the intended objective.

Throughout the research, it was noticed, when adding the patents and industrial designs, that there is a diversity of classes of products, and that there is a predominance of projects coming from individuals and from private institutions. Also, the South and Southeast regions were the ones that registered more requests of protection, and that the majority of the inventors were from the areas of Engineering, Medicine, and Design.

The main results indicated that: (i) there is a diversity of classes of products, and that the largest number of projects is related to facial protection equipment because of the high demand and importance in containing the spread of the virus; (ii) regarding the academic background of the inventors, the majority were from the areas of Engineering, Medicine, or Design; (iii) most orders came from the Southeastern and Southern regions.

It is important to point out that there are projects still under development, some have been interrupted, and others are being commercialized or have been disseminated and published in events, magazines, periodicals, among other means. However, due to the purpose of this research, the search was restricted to the INPI database. Thus, as suggestions for future work, it is recommended to identify the quantitative and qualitative aspects of the projects developed in Brazil, in the context of COVID-19, published in different media.

Regarding the INPI platform, for both Patent and Industrial Design, the search process proved to be effective to meet the research objectives, however, it is clear that filling in the data and applying filters could make it more efficient. As a result, it is recommended for future work an evaluation of software usability, by means of technological methods and instruments capable of confirming such finding.

Finally, the development of this study allowed to identify a gap in systematic search procedures for industrial property registrations, thus opening an opportunity for future works to delve into that.

\section{Acknowledgements}

We are grateful to the Assistive Technology Research and Development Network (RPDTA), the National Council for Scientific and Technological Development $(\mathrm{CNPq})$, the Design Management and Design and Usability Laboratory Group (NGD-LDU), the Design Graduate Program (POSDESIGN), the Production Engineer Graduate Program (PPGEP) and to the Federal University of Santa Catarina (UFSC). This work was carried out with the support of the Coordination for the Improvement of Higher Education Personnel - Brazil (CAPES) - Financing Code 001.

\section{References}

Aires, R. O. S. (2020). Hospital de campanha como solução emergencial para o atendimento hospitalar de pacientes infectados pela COVID-19. Revista da FAEFS, 4, 40-42.

Bagattolli, C., \& Dagnino, R. P. (2013). Política de estímulo às patentes no brasil: avançando na contramão? Revista Economia \& Tecnologia, 9(3), 73-86.

Belhouideg, S. (2020). Impacto de equipamentos médicos impressos em 3D no gerenciamento da pandemia COVID-19. The International Journal of Health Planning and Management, 35(5), 1014-1022. http://dx.doi.org/10.1002/hpm.3009.

Biachini, I. M. E., \& Russo, S. L. (2019). Propriedade intelectual e desenvolvimento regional: artesanato com indicação geográfica no Brasil. Revista INGI, 3(2), 333-347.

Brasil. Ministério da Agricultura, Pecuária e Abastecimento. (1996, May 15). Lei nº 9.279, de 14 de maio de 1996. Regula direitos e obrigações relativos à propriedade industrial. Diário Oficial [da] República Federativa do Brasil, Brasília.

Brasil. Ministério da Saúde. (2020). COVID-19: painel coronavírus. Retrieved in 2020, December 20, from

https://covid.saude.gov.br/ 
Briede-Westermeyer, J. C., Pérez-Villalobos, C. E., Bastías-Vega, N., Bustamante-Durán, C. E., Olivera-Morales, P., Parra-Ponce, P., Delgado-Rivera, M., Cabello-Mora, M., \& Campos-Cerda, I. (2017). Experiencia interdisciplinaria para el diseño de productos para la salud. Revista Medica de Chile, 145(10), 1289-1299. http://dx.doi.org/10.4067/S0034-98872017001001289.

Buainain, A. M., \& Souza, R. F. Propriedade Intelectual, Inovação e Desenvolvimento: desafios para o Brasil. Rio de Janeiro: ABPI; 2018

Casas, C. P. R., Silva, J., Castro, R., Ribeiro-Alves, M., \& Franco, C. M. (2020). Avaliação de tecnologias em saúde: tensões metodológicas durante a pandemia de COVID-19. Estudos Avançados, 34(99), 77-96. http://dx.doi.org/10.1590/s01034014.2020.3499.006

Chu, D. K., Akl, E. A., Duda, S., Solo, K., Yaacoub, S., Schünemann, H. J., Chu, D. K., Akl, E. A., El-harakeh, A., Bognanni, A., Lotfi, T., Loeb, M., Hajizadeh, A., Bak, A., Izcovich, A., Cuello-Garcia, C. A., Chen, C., Harris, D. J., Borowiack, E.,

Chamseddine, F., Schünemann, F., Morgano, G. P., Muti Schünemann, G. E. U., Chen, G., Zhao, H., Neumann, I., Chan, J., Khabsa, J., Hneiny, L., Harrison, L., Smith, M., Rizk, N., Giorgi Rossi, P., AbiHanna, P., El-khoury, R., Stalteri, R., Baldeh, T., Piggott, T., Zhang, Y., Saad, Z., Khamis, A., Reinap, M., Duda, S., Solo, K., Yaacoub, S., \& Schünemann, H. J. (2020). Physical distancing, face masks, and eye protection to prevent person-to-person transmission of SARS-CoV-2 and COVID-19: a systematic review and meta-analysis. Lancet, 395(10242), 1973-1987. http://dx.doi.org/10.1016/S0140-6736(20)31142-9.

Confederação Nacional da Indústria - CNI. (2014). Propriedade intelectual: as mudanças na indústria e a nova agenda. Brasília: CNI.

Croda, J., Oliveira, W. K., Frutuoso, R. L., Mandetta, L. H., Baia-da-Silva, D. C., Brito-Sousa, J. D., Monteiro, W. M., \& Lacerda, M. V. G. (2020). COVID-19 in Brazil: advantages of a socialized unified health system and preparation to contain cases. Revista da Sociedade Brasileira de Medicina Tropical, 53, e20200167. http://dx.doi.org/10.1590/0037-8682-0167-2020.

Donato, H., \& Donato, M. (2019). Etapas na condução de uma revisão sistemática. Acta Médica Portuguesa, 32(3), $227-235$. http://dx.doi.org/10.20344/amp.11923.

Ferreira, A. A., Guimarães, E. R., \& Contador, J. C. (2009). Patente como instrumento competitivo e como fonte de informação tecnológica. Gestão \& Produção, 16(2), 209-221. http://dx.doi.org/10.1590/S0104-530X2009000200005.

Garcia, L. P. (2020). Uso de máscara facial para limitar a transmissão da COVID-19. Epidemiologia e Serviços de Saúde: Revista do Sistema Unico de Saúde do Brasil, 29(2), e2020023. http://dx.doi.org/10.5123/S1679-49742020000200021.

Girardi, J. M., Andrade, A. M., \& Silva, E. T. (2020). Informe técnico: o uso de máscaras para a prevenção e controle da COVID19. Brasília: Fiocruz.

Instituto Nacional da Propriedade Industrial - INPI. (2016). Decreto $n^{\circ} 8.854$, de 22 de setembro de 2016. Retrieved in 2020 , December 20, from https://www.gov.br/inpi/pt-br/acesso-a-informacao/institucional

Instituto Nacional da Propriedade Industrial - INPI. (2020a). Desenho industrial. Retrieved in 2020, December 20, from https://www.gov.br/inpi/pt-br/servicos/desenhos-industriais

Instituto Nacional da Propriedade Industrial - INPI. (2020b). Patentes. Retrieved in 2020, December 20, from https://www.gov.br/inpi/pt-br/servicos/patentes

Jefferson, T., Del Mar, C. B., Dooley, L., Ferroni, E., Al-Ansary, L. A., Bawazeer, G. A., van Driel, M. L., Nair, S., Jones, M. A. Thorning, S., \& Conly, J. M. (2011). Physical interventions to interrupt or reduce the spread of respiratory viruses. Cochrane Database of Systematic Reviews, 2011(7), CD006207. http://dx.doi.org/10.1002/14651858.CD006207.pub4.

Khan, M. M., \& Parab, S. R. (2020). Safety guidelines for sterility of face shields during COVID-19 pandemic. Indian Journal of Otolaryngology and Head and Neck Surgery, 73(1), 1-2. https://doi.org/10.1007/s12070-020-01865-2.

Klosowski, A. L. M., Kuasoski, M., \& Bonetti, M. B. P. (2020). Apicultura brasileira: inovação e propriedade industrial. Revista de Política Agrícola, (1), 41-58.

Loiola, E., \& Mascarenhas, T. (2013). Gestão de ativos de Propriedade Intelectual: um estudo sobre as práticas da Braskem S.A. Revista de Administração Contemporânea, 17(1), 42-63. http://dx.doi.org/10.1590/S1415-65552013000100004.

Marconi, M. A., \& Lakatos, E. M. (2011) Fundamentos de metodologia cientifica (6. ed.). São Paulo: Atlas.

Mueller, S. P. M., \& Perucchi, V. (2014). Universidades e a produção de patentes: tópicos de interesse para o estudioso da informação tecnológica. Perspectivas em Ciência da Informação, 19(2), 15-36.

Noronha, K. V. M. S., Guedes, G. R., Turra, C. M., Andrade, M. V., Botega, L., Nogueira, D., Calazans, J. A., Carvalho, L., Servo, L., \& Ferreira, M. F. (2020). Pandemia por COVID-19 no Brasil: análise da demanda e da oferta de leitos hospitalares e equipamentos de ventilação assistida segundo diferentes cenários. Cadernos de Saude Publica, 36(6), e00115320. http://dx.doi.org/10.1590/0102-311x00115320.

Oliveira, B. S., Frey, I. A., \& Erdmann, R. H. (2018). Funil de patentes: metodologia para indução ao registro da propriedade industrial. Florianópolis.

Oliveira, J. F. G., \& Telles, L. O. (2011). O papel dos institutos públicos de pesquisa na aceleração do processo de inovação empresarial no Brasil. Revista USP, (89), 204-217.

Oliveira, M. A. C., Mendes, D. R. F., Moreira, T. B. S., \& Cunha, G. H. M. (2015). Análise econométrica dos dispêndios em pesquisa \& desenvolvimento (P\&D) no Brasil. Review of Administration and Innovation, 12(3), 268-286.

Oliveira, R. M., \& Velho, L. M. L. S. (2010). Patentes acadêmicas no Brasil: uma análise sobre as universidades públicas paulistas e seus inventores. Parcerias Estratégicas, 14(29), 173-200

Page, M. J., Moher, D., Bossuyt, P. M., Boutron, I., Hoffmann, T. C., Mulrow, C. D., Shamseer, L., Tetzlaff, J. M., Akl, E. A., Brennan, S. E., Chou, R., Glanville, J., Grimshaw, J. M., Hróbjartsson, A., Lalu, M. M., Li, T., Loder, E. W., Mayo-Wilson, E., McDonald, S., McGuinness, L. A., Stewart, L. A., Thomas, J., Tricco, A. C., Welch, V. A., Whiting, P., \& McKenzie, J. E. (2021). PRISMA 2020 explanation and elaboration: updated guidance and exemplars for reporting systematic reviews. $B M J, 372(160)$. http://dx.doi.org/10.1136/bmj.n160. 
Rache, B., Rocha, R., Nunes, L., Spinola, P., Malik, A. M., \& Massuda, A. (2020). Necessidades de infraestrutura do SUS em preparo ao COVID-19: leitos de UTI, respiradores e ocupação hospitalar (Nota Técnica, No. 3). São Paulo: Instituto de Estudos para Políticas de Saúde.

Saraiva, E. M. S., Ricarte, E. C., Coelho, J. L. G., Sousa, D. F., Feitosa, F. L. S., \& Alves, R. S. (2020). Modelo de protocolo para realização de Traqueostomia em leito de UTI no paciente com COVID-19. Brazilian Journal of Development, 6(8), 67955-67964.

Shokrani, A., Loukaides, E. G., Elias, E., \& Lunt, A. (2020). Exploration of alternative supply chains and distributed manufacturing in response to COVID-19: a case study of medical face shields. Materials \& Design, 192, 108749. http://dx.doi.org/10.1016/j.matdes.2020.108749.

Sichel, R. L. (2020). Intellectual property: element of economic development. Revista da Propriedade Industrial Online, 32(3), 117-124.

Silva, M. B., Sousa, M. C. N. D., Camargo, M. E., Priesnitz, M. C., \& Russo, S. L. (2019). Propriedade intelectual e desempenho: uma análise bibliométrica. Revista INGI, 3(2), 361-377.

Souza, M. G., \& Farias, R. F. (2020). COVID-19: da (in) eficácia do uso de máscaras: uma breve revisão. Mens Agitat, 15, 142-144.

Suzumura, E. A., Zazula, A. D., Moriya, H. T., Cristina, Q. A. F., Alvarado, A. L., Cavalcanti, A. B., \& Rodrigues, R. G. (2020). Desafios para o desenvolvimento de ventiladores alternativos de baixo custo durante a pandemia de COVID-19 no Brasil. Revista Brasileira de Terapia Intensiva, 32(3), 444-457. http://dx.doi.org/10.5935/0103-507x.20200075.

Uchoa, N. N., Pereira, R. P., Sachetto-Martins, G., \& Muller, A. C. (2011). Ten years of the genomic era in Brazil: impacts on technological development assessed by scientific production and patent analysis. World Patent Information, 33(2), 150-156.

van der Sande, M., Teunis, P., \& Sabel, R. (2008). Professional and home-made face masks reduce exposure to respiratory infections among the general population. PLoS One, 3(7), e2618. http://dx.doi.org/10.1371/journal.pone.0002618.

Wang, X., Pan, Z., \& Cheng, Z. (2020). Association between 2019-nCoV transmission and N95 respirator use. The Journal of Hospital Infection, 105(1), 104-105. http://dx.doi.org/10.1016/j.jhin.2020.02.021.

World Intellectual Property Organization - WIPO. (2009). Manual de la OMPI de redaccion de solicitudes de patentes. Retrieved in 2020, December 20, from https://www.wipo.int/edocs/pubdocs/es/patents/867/wipo_pub_867.pdf

World Intellectual Property Organization - WIPO. (2016). DL 101: general course on intellectual property: session 2. Retrieved in 2020, December 20, from https://www.wipo.int/portal/en/

World Intellectual Property Organization - WIPO. (2020). Índice global de inovação 2020: quem financiará a inovação? (Report). Universidade Cornell.

Wu, D., Wu, T., Liu, Q., \& Yang, Z. (2020). The SARS-CoV-2 outbreak: what we know. International Journal of Infectious Diseases, 94, 44-48. http://dx.doi.org/10.1016/j.ijid.2020.03.004. 